\title{
Rodzina polska w XIX wieku jako środowisko wychowawcze i jej funkcja edukacyjna
}

The Polish Family as an Educational Environment in the $19^{\text {th }}$ Century, and Its Educational Function

\begin{abstract}
ABSTRAKT
Niniejsze opracowanie poświęcone jest naturalnemu środowisku wychowawczemu, jakim jest rodzina. Przedmiotem badań uczyniono jej funkcję edukacyina, ze szczególnym uwzględnieniem charakterystyki jej uwarunkowań, przejawów i sposobów realizacji. Podjęto się charakterystyki specyfiki modelu rodziny polskiej w XIX wieku, dokonujących się w nim przemian i warunkujących je czynników. Można stwierdzić, iż upowszechniany $w$ XIX stuleciu model rodziny jako środowiska wychowawczego był na tyle uniwersalny, a nawet atrakcyjny, że mógł być i bywał przyjmowany przez rodziny z różnych warstw społecznych. Sq̨dzono, że każda rodzina bez względu na ¡j status społeczny jest pierwszym i najważniejszym środowiskiem wychowawczym. Każda rodzina bowiem, bez względu na jej miejsce w stratyfikacji społecznej, pełniła znaczqca funkcję edukacyina
\end{abstract}

SLOWA KLUCZOWE rodzina polska, wychowanie w rodzinie, funkcja edukacyina rodziny, zabory, XIX wiek

\section{KEYWORDS}

family, Polish family at XIX century, family upbringing, educational function of the family

SPI Vol. 19, 2016/2

ISSN 2450-5358

e-ISSN 2450-5366 DOI: 10.12775/SPI.2016.2.001

Artykuły i rozprawy 
i kształtowała osobowość dzieci całokształtem organizacji i treści swego życia. Funkcja edukacyjna rodziny przejawiała się w wyznawanym i wpajanym młodemu pokoleniu systemie wartości, atmosferze domu, występujących w rodzinie wzorach zachowań, układzie stosunków i relacji w niej panujących, podziale ról rodzinnych, czynnościach wykonywanych przez poszczególnych jej członków - domowników. Opisany model rodziny i realizacja funkcji edukacyjnej na jej gruncie podlegały zmianom wraz z przemianami cywilizacyinymi i społeczno-ekonomicznymi, które dokonywały się już od pierwszych dekad XX wieku.

\section{ABSTRACT}

In the history of Poland the family has determined for centuries not only the vitality of family traditions, but also the shaping of the face of the nation, its mentality, and scale of openness. Especially in the $19^{\text {th }}$ and the early $20^{\text {th }}$ century, the "institution" of the family home played a unique role. This was due, inter alia, to the political situation experienced by the Polish nation under the partitions. The family model popularized in the $19^{\text {th }}$ century was so versatile, and even attractive, that it could be, and was, frequently adopted by families from different social classes. The majority of $19^{\text {th }}$-century educators and journalists did not particularly distinguish between the educational functions to be met by families belonging to various social classes. It was believed that every family, regardless of its social status, was the first and most important educational environment. For it was the family, regardless of its place in the social stratification, that performed an important educational function, and shaped the personality of children through the entirety of its organization, and the content of its life. The educational function of the family manifested itself in the system of values, home atmosphere, patterns of behaviour occurring in the family, the system of relations and relationships prevailing in it, the division of family roles, and the activities performed by each of its members-the household, professed by and instilled in the younger generation. It was in the family, from the parents, grandparents, and its other members that children learnt the Polish language, respect for local traditions, the principles of the Catholic faith, piety, and patriotism. A special role in the implementation of educational functions, regardless of social class, was attributed to the mother as the patron of hearth and home, the first teacher of the mother tongue and the principles of the faith. Education in the family was to supplement or replace education in the state schools of the partition powers. The described model of the family was subject to alterations along with the civilizational and socio-economic changes that were taking place already during the early decades of the $20^{\text {th }}$ century. 


\section{Wprowadzenie - ustalenia terminologiczne}

Niniejsze opracowanie poświęcone jest naturalnemu środowisku wychowawczemu, jakim jest rodzina. Przedmiotem badań uczyniono jej funkcję edukacyjną, ze szczególnym uwzględnieniem charakterystyki jej uwarunkowań, przejawów i sposobów realizacji. Cezury czasowe obejmują okres wieku XIX, czas, kiedy Polska znajdowała się pod władaniem trzech zaborców - Rosji, Austrii i Prus ${ }^{1}$.

Jest oczywiste, iż rodzina ma ogromne znaczenie dla edukacji młodego pokolenia. Można ją nazwać pierwszą szkołą, w której dziecko uczy się zasad życia społecznego i funkcjonowania w świecie. „Środowisko rodzinne bowiem, jako pierwsze i najbliższe, najintensywniej oddziałuje na dziecko, przetwarzając jego cechy wrodzone, temperamentalne, biopsychiczne w cechy nabyte, które z kolei wpływają na

1 Problematyka dziejów wychowania w rodzinie i jej roli w edukacji młodego pokolenia, ze szczególnym uwzględnieniem XVIII, XIX i XX wieku od lat 90. XX wieku stały się obszarem zainteresowań historyków wychowania z całej Polski. Zob. np.: Wychowanie w rodzinie od starożytności po wiek XX, red. J. Jundziłł, Bydgoszcz 1994; Rodzina jako środowisko wychowawcze w czasach nowożytnych, red. K. Jakubiak, Bydgoszcz 1995; Rodzina pomorska, red. J. Borzyszkowski, Gdańsk 1999; Wychowanie w rodzinie polskiej od schytku XVIII do potowy XX wieku, red. K. Jakubiak, A. Winiarz, Bydgoszcz 2000; Partnerka, matka, opiekunka. Status kobiety w dziejach nowożytnych od VI do XX wieku, red. K. Jakubiak, Bydgoszcz 2000; Źródta do dziejów wychowania w rodzinie polskiej w XIX i początkach XX wieku, wybór i oprac. A. Denisiuk, K. Jakubiak, Bydgoszcz 2001; Dziecko w rodzinie i spoteczeństwie. Dzieje nowożytne, red. K. Jakubiak, W. Jamrożek, Bydgoszcz 2002; Nauczanie domowe dzieci polskich od XVIII do XX wieku, red. K. Jakubiak, A. Winiarz, Bydgoszcz 2004; Źródta do nauczania domowego dzieci polskich w XIX i na początku XX wieku $z$ bibliografiq adnotowana pamiętników $i$ wyborem literatury pedagogicznej, red. K. Jakubiak, G. Karłowska, M. Nawrot, A. Winiarz, Bydgoszcz 2005; Rodzina - prywatność - intymnośc. Dzieje rodziny polskiej w kontekście europejskim, red. D. Kałwa, A. Walaszek, A. Żarnowska, Warszawa 2005; A. Bołdyrew, Matka i dziecko w rodzinie polskiej. Ewolucja modelu życia rodzinnego w latach 1795-1918, Warszawa 2008; Rodzina. Historia i wspótczesnośc. Studium monograficzne, red. W. Korzeniowska, U. Szuścik, Kraków 2010; M. Nawrot-Borowska, Nauczanie domowe na ziemiach polskich w II potowie XIX i na poczatku XX wieku - zapatrywania teoretyczne i praktyka, Bydgoszcz 2011; Wychowanie w rodzinie. Przekaz tradycji i kultury na przestrzeni wieków, t. 1 i 2, red. S. Walasek, L. Albański, Jelenia Góra 2011; Wychowanie w rodzinie. Od starożytnej myśli filozoficznej do wspótczesnych rozwiq̨zań legislacyjnych, t. 7, red. B. Jędrychowska, E. Jurczyk-Romanowska, Wrocław - Jelenia Góra 2013; Wychowanie w rodzinie. Rodzina w Europie na przetomie XIX i XX wieku, t. 12, red. S. Walasek, A. Haratyk, Wrocław 2016. 


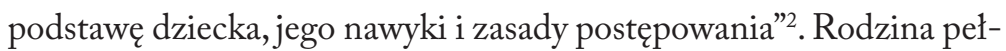
niła i pełni szereg funkcji ${ }^{3}$. Kluczową dla niniejszych ustaleń funkcję edukacyjną rodziny zdefiniował Andrzej M. Tchorzewski, określając ją jako „szczególny skutek działań, czynności, zachowań i postępowania rodziców" ", będący pochodną i składową funkcji, którą socjologowie i pedagodzy nazywają funkcją socjalizacyjno-wychowawczą.

Funkcja edukacyjna wiąże się bezpośrednio z faktem przyjścia jednostki na świat w określonej rodzinie, gdzie zastaje ona przedmioty, urządzenia, poglądy, wierzenia i systemy wartości, a także normy postępowania regulujące zachowania poszczególnych podmiotów rodziny. Jednostka styka się z określoną subkulturą rodziny swojego pochodzenia, ulega jej wpływowi, a zarazem uczy się, przyswaja sobie szczegółowe treści o danej subkulturze. Jej wpływowi będzie ona poddana od momentu urodzenia przez wiele długich lat swojego życia, nawet, choć w ograniczonym zakresie, po pełnym lub tylko częściowym usamodzielnieniu się.

Funkcja edukacyjna ma więc nie tylko znaczenie prywatne, osobiste - dla samej jednostki, która podlega jej działaniu i jest niejako efektem i skutkiem jej oddziaływania, bowiem droga życiowa, losy i wybory dziecka, są wypadkową i skutkiem oddziaływań edukacyjnych rodziny, ale ma ona i znaczenie ogólnospołeczne, kształtując sposoby postępowania i system wartości kolejnego pokolenia ${ }^{6}$.

Realizacja zamierzenia badawczego nie jest zdaniem łatwym, ze względu na złożoność problemu głównego niniejszych ustaleń. Należy mieć świadomość, iż „w kręgu rodzinno-domowym, niczym w soczewce, skupiały się wszystkie zjawiska cywilizacyjne, mentalnościowe, obyczajowe i polityczne" . W XIX wieku bowiem funkcje edukacyjne rodziny zależne były od wielu czynników zewnętrznych, głównie politycznych, ale i gospodarczych, społeczno-kulturalnych

2 R. Skrzypniak, Rodzina - mata ojczyzna wychowawcza, „Roczniki Socjologii Rodziny"1998, t. 10, s. 202.

3 Zob. np.Z. Tyszka, Rodzina, w: Encyklopedia Pedagogiczna, red.W.Pomykało, Warszawa 1993, s. 698.

4 A.M. Tchorzewski, Funkcje edukacyjne rodziny. Studium diagnostyczno-anagnostyczne, Bydgoszcz 1990, s. 29.

5 Tamże.

6 Tamże.

7 D. Kałwa, Polska doby rozbiorów i międzywojenna, w: Obyczaje w Polsce. Od średniowiecza do czasów wspótczesnych, red. A. Chwalba, Warszawa 2008, s. 242. 
warunków życia społeczeństwa. Odmiennie funkcjonowały poszczególne typy rodzin w ówczesnej strukturze społecznej - arystokratyczne, ziemiańskie, mieszczańskie (inteligenckie, burżuazyjne czy robotnicze), chłopskie, w odmiennych warunkach każdego z zaborów - rosyjskiego, pruskiego i austriackiego. Nie można zapominać też o czynnikach wewnętrznych, dotyczących już samej, pojedynczej rodziny i jej funkcjonowania, w tym świadomości pedagogicznej i wychowawczej rodziców i pozostałych jej członków, relacji między nimi, warunków materialnych, wyznawanego systemu wartości, stosunku do wiary i religii. Nie da się więc w niniejszym opracowaniu uniknąć pewnych uogólnień, zaś ustalenia dotyczące realizacji funkcji edukacyjnej w poszczególnych typach rodzin na terenach ziem polskich pod zaborami, a szczególnie jej skutków (ze świadomością zarówno tych pozytywnych, jak i negatywnych), wymagają dodatkowych, pogłębionych analiz źródłowych.

Analizując XIX-wieczne zasoby leksykalne i publikacje pedagogiczne, należy stwierdzić, iż brakuje w nich jasno sprecyzowanej definicji edukacji w domu rodzinnym czy funkcji edukacyjnej rodziny. Mimo że powszechnie zwracano uwagę na rolę i znaczenie rodziny w edukacji, wychowaniu i kształceniu młodego pokolenia, nie wypracowano konkretnych ustaleń terminologicznych na ich określenie. Często, dla określenia oddziaływań edukacyjnych w domu rodzinnym, zamiennie używano pojęć: wychowanie domowe, kształcenie domowe, nauczanie domowe. Dla przykładu warto tu przytoczyć pojęcie „kształcenia domowego” (zamieszczone w Encyklopedii Wychowawczej z końca XIX wieku), które adekwatnie oddaje cele i rezultaty działalności edukacyjnej, jaką jest edukacja, wychowanie i kształcenie $\mathrm{w}$ domu rodzinnym. Jest ono bowiem pojmowane jako

całokształt takich poczynań, czynności, procesów i metod oddziaływania na jednostkę, których efektem było wykształcenie ogólne osoby, czyli zdobycie kompetencji i kwalifikacji ogólnych. Przez tak pojęte kształcenie rozumie się opanowanie podstaw wiadomości, umiejętności, nawyków, dorobienia się własnych poglądów, przekonań, rozwój zdolności i zainteresowań ${ }^{8}$.

8 Encyklopedia wychowawcza, red. J. Lubomirski, E. Stawski, S. Przystański,J.K. Plebański, Warszawa 1881, s. 240. 
Przez dom - utożsamiany z rodziną - ówczesna pedagogika rozumiała całokształt stosunków, wśród których człowiek się rodzi, wychowuje i wyrasta na członka społeczeństwa. Dom, w szerokim tego słowa znaczeniu, był traktowany jako miejsce szczególne, w którym przekazywało się wiarę ojców, cnoty, tradycje oraz pamiątki rodzinne i narodowe ${ }^{9}$. Był więc dom istotną przestrzenią, w której realizowały się funkcje edukacyjne i oddziaływania wychowawcze rodziny wobec zamieszkującego w nim młodego pokolenia, często z nim od narodzin do śmierci związanego.

\section{Rodzina polska w XIX wieku jako środowisko wychowawcze}

Rodzina w dziejach Polski przez wieki decydowała o żywotności nie tylko rodzinnych tradycji, ale także o kształtowaniu oblicza narodu, jego mentalności i skali otwartości. Szczególnie w XIX wieku i na początku XX stulecia „instytucja” domu rodzinnego odegrała wyjątkową rolę. Było to spowodowane głównie, ale nie tylko, ówczesną sytuacją polityczną, w jakiej znalazł się naród polski w okresie zaborów. Józef Chałasiński pisał ten temat następująco: „W polskim klimacie intelektualnej refleksji nad problemami narodu w czasie zaborów, tym większe znaczenie miały wszystkie sposoby pielęgnowania i wzbogacania kultury narodowej w oparciu o dom i rodzinę"10.

Należy tu podkreślić, iż w XIX wieku w Europie Zachodniej pod wpływem różnorodnych procesów społecznych zaszły zmiany w strukturze, spoistości i systemie wartości ówczesnych rodzin ${ }^{11}$. Procesy industrializacji i urbanizacji zmieniały życie całych społeczeństw i rodzin. Oddzielenie rodzin od warsztatu pracy, praca rodziców poza domem, rozluźnienie kontroli i więzi społecznej w środowiskach miejskich sprzyjały procesom transformacji - stopniowym, ale konsekwentnym oddalaniu się od tradycyjnego, ustalonego przez wieki modelu rodziny, w kierunku modelu współczesnego, rodziny nukle-

9 Dom, w: tamże, t. 3, Warszawa 1885, s. 283, za: K. Jakubiak, Edukacja rodziców w polskiej refleksji i praktyce pedagogicznej XIX i XX wieku - do 1939 roku, w: Wychowanie w rodzinie polskiej XIX i XX wieku, dz. cyt., s. 125.

10 J. Chałasiński, Kultura i naród, Warszawa 1968, s. 40.

11 A. Regulska, Przeobrażenia w modelu i funkcjach rodziny na przestrzeni XIX-XX wieku, „Studia nad Rodziną” 2011, nr 1-2, s. 236. 
arnej, o zredukowanej liczbie funkcji ${ }^{12}$. Trzeba tu również pamiętać o fakcie, że rodzina, jako środowisko wychowawcze, była i jest nadal stosunkowo mało podatna na zmiany i innowacje wychowawcze. Raczej, zarówno w przeszłości, jak i obecnie, kontynuuje tradycyjne sposoby wychowania. Dlatego też jej rola i funkcje były podważane i krytykowane w kolejnych rewolucjach społecznych, począwszy od burżuazyjnej Wielkiej Rewolucji Francuskiej. Mimo wyraźnych tendencji głębokich zmian, mających miejsce w Europie Zachodniej, w strukturze ludności na ziemiach polskich w XIX wieku ciągle jeszcze dominowała ludność chłopska - w Królestwie Polskim ok. 80\%, ponad 85\% w Galicji, w mniejszym stopniu w Wielkopolsce. W miastach zamieszkiwało kilkanaście procent ludności dawnej Rzeczypospolitej. Świadczy to o zacofaniu urbanizacyjnym, procesie silnie wówczas związanym z kształtowaniem się kapitalistycznego sposobu produkcji i gospodarowania ${ }^{13}$. Dopiero na przełomie XIX i XX wieku procesy urbanizacji i industrializacji spowodowały na ziemiach polskich coraz bardziej znaczące przemiany w strukturze społecznej i zawodowej, z wyłanianiem się nowych klas i warstw społecznych. Jednym z charakterystycznych zjawisk życia rodzinnego na ziemiach polskich było stopniowe poddanie instytucji rodziny uregulowaniom prawnym. Ówczesne fundamentalne zbiory przepisów to: „Pruskie Powszechne Prawo Krajowe” oraz „Kodeks Napoleona”. Prawo świeckie zastępowało dotychczasowe regulacje prawa kościelnego, wprowadzając między innymi małżeństwa cywilne, a także rozwody ${ }^{14}$.

Ówczesny kierunek ewolucji rodziny i jej funkcji trafnie wówczas przewidywał i opisywał Emil Durkheim, twierdząc, że wraz z procesem rozszerzania się społeczeństwa następuje proces zawężania się rodziny ${ }^{15}$.

Jedną z konsekwencji prądów oświeceniowych był ówczesny przełom w spojrzeniu na miejsce dziecka w rodzinie i społeczeństwie. Dzięki znanym i przyswojonym w polskiej kulturze pismom Jana Jakuba Rousseau rozpoczął się proces mentalnej rewolucji w po-

12 Tamże.

13 M. Żyrowski, Dziewiętnastowieczna rodzina polska, ,Roczniki Socjologii Rodziny”, Poznań 2000, z. 12, s. 173-177.

14 Tamże, s. 182.

15 E. Durkheim, Introduction à la sociologie de la famille, w: tenże, Textes 3. Fonctions sociales et institutions, Paris 1975, s. 14. 
strzeganiu dzieci i ich roli w rodzinach. Stopniowo ten okres życia dzieciństwo, przez wieku tak bardzo niedoceniany w ówczesnym dyskursie filozofów, pisarzy, lekarzy, moralistów i pedagogów nabrał coraz większego znaczenia. Były też już zauważalne, choć oczywiście jeszcze nie powszechne, przemiany w życiu ówczesnych rodzin. Charakteryzowały je coraz bardziej uczuciowe relacje między rodzicami a dziećmi oraz skupienie się na nich. Dzieci stawały się źródłem radości i satysfakcji rodziców ${ }^{16}$.

Nowe sposób traktowania dziecka, zainicjowane w piśmiennictwie europejskim przez prekursorów wychowania macierzyńskiego: Jana Amosa Komeńskiego, Jana Jakuba Rousseau, Jana Henryka Pestalozziego, Fryderyka Froebla, od przełomu XVIII i XIX wieku zdobywało sprzymierzeńców w większości krajów europejskich. W polskim piśmiennictwie jednym z pierwszych propagatorów tych wzorów był Jędrzej Śniadecki, autor pracy O fizycznym wychowaniu dzieci (1805).

Polskie piśmiennictwo okresu oświecenia i czasów romantyzmu dostrzegało i wysoko oceniało społeczne znaczenie wychowania rodzinnego. Od lat 40. XIX wieku, zwłaszcza w pracach Karola Libelta i Edwarda Dembowskiego, wyrażane były postulaty dotyczące przełamywania bezwzględnego zwierzchnictwa ojca w rodzinie i przyznania matce większej samodzielności w decydowaniu o sprawach rodziny i dzieci. Literatura romantyczna zwracała uwagę na bogactwo życia uczuciowego dziecka, poznawania jego natury i liczenia się $\mathrm{z}$ nią ${ }^{17}$.

W dobie zaborów rodzina na ziemiach polskich zyskiwała rangę szczególną. Ówcześni filozofowie, publicyści i pedagodzy w publicznym dyskursie na temat narodu i jego tożsamości nieustannie podnosili rolę środowiska domowego, przyznając mu status wręcz priorytetowy ${ }^{18}$, głosząc jednocześnie, szczególnie w drugiej połowie

16 P. Ariès, Historia dzieciństwa. Dziecko i rodzina w dawnych czasach, przeł. M. Ochab, Gdańsk 1995, s. 188 i nast.

17 J. Sobczak, Przejawy zainteresowania wychowaniem rodzinnym w pracach niektórych polskich pisarzy i pedagogów u schytku XVIII i w pierwszej potowie XIX wieku, „Zeszyty Naukowe Wyższej Szkoły Pedagogicznej w Bydgoszczy. Studia Pedagogiczne”, Bydgoszcz 1992, z. 18, s. 95-107.

18 A. Bołdyrew, Matka i dziecko w rodzinie polskiej, dz. cyt., s. 315-316. 
XIX wieku, swoistą „ideologię rodzinną”19. W myśl jej założeń, geneza rodziny jawiła się jako nadprzyrodzona. Podobnie były ujmowane główne elementy koncepcji małżeństwa: związek małżeński jest powołany przede wszystkim do prokreacji, jest węzłem nierozerwalnym, obwarowanym nakazem wierności. Żona winna jest mężowi posłuszeństwo, a mąż żonie opiekę. Najważniejszym celem było wychowanie młodego pokolenia, w którym to procesie ważną rolę odgrywała tradycja. Rodziny zamożne i wykształcone, zwłaszcza ziemiańskie, miały dawać przykład swoim życiem rodzinom uboższym, miały je umoralniać i oświecać. Inne rodziny miały ten wzór naśladować, dostosowując go do własnych warunków życiowych ${ }^{20}$.

Publicyści pism rodzinnych podkreślali, że zadaniem rodziny jest przekazywać pokoleniowo wartości „niezniszczalne”: tradycję narodową, język i wiarę. Wartości te traktowano jako ostoję polskości. Zarówno pisma rodzinne, jak i codzienne, np. pomorskie: „Gazeta Grudziądzka”, „Gazeta Toruńska”, „Pielgrzym” czy też śląski „Katolik” z uporem eksponowały szczególną rolę „Matki - Polki” - ówczesną konstrukcję wzoru wchłaniającego tradycje kultury dworu szlacheckiego, polskiego katolicyzmu i kultury ludowej ${ }^{21}$. W przywoływanych wówczas cechach tego wizerunku obecne były treści romantycznej wizji wieszcza Adama Mickiewicza, zawartej w wierszu pt. Do matki Polki. Miała to być kobieta o wysokich wartościach moralnych, heroiczna, gotowa do ofiar i wspierająca męża (powstańca i konspiratora), wierna, oddana. Upowszechniano także określenia utożsamiające matkę z Ojczyzną, wyrażane najczęściej w formule: „Polska jest matką naszą”. Ten etos „Matki - Polki” był niewątpliwie związany rozpowszechnionym wśród Polaków „kultem maryjnym”, stąd też osoba matki zyskiwała w polskich warunkach i rodzinach

19 K. Lutyńska, Ideologia czasopism rodzinnych Królestwa Polskiego w latach 1860-1880, „Przegląd Nauk Historycznych i Społecznych” 1956, t. 7, s. 289-329; D. Rzepniewska, Rodzina ziemiańska w Królestwie Polskim, w: Spoteczeństwo polskie XVIII i XIX wieku. Studia o rodzinie, t. 9, red.J. Leskiewiczowa, Warszawa 1991, s. 137-200.

20 Tamże.

21 R. Grzybowski, Zadania wychowawcze rodziny polskiej na Pomorzu Nadwiślańskim w ujęciu "Gazety Grudziadzkiej” z lat 1894-1914, w: Wychowanie w rodzinie od starożytności po wiek XX, dz. cyt., s. 295; B. Jedynak, Dom i kobieta w kulturze nierwoli, w: Kobieta w kulturze i spoteczeństwie, red. B. Jedynak, Lublin 1990, s. 70-90. 
szczególny prestiż i znaczenie, w tym wychowawcze: przekazywania młodszemu pokoleniu tradycji i wartości narodowych - patriotyzmu i religijności ${ }^{22}$.

XIX-wieczne modele życia rodzinnego były warunkowane kulturowo, polityką państw zaborczych, tradycją, w tym religijną i systemem prawnym ${ }^{23}$. Nie bez znaczenia były też zapewne wpływy Kościoła katolickiego i lokalne powiązania. Treści pochodzące z każdego z tych źródeł były ze sobą zgodne i adekwatne do danych warunków bytowania. Czynniki te kreowały jeszcze w XIX wieku model rodziny patriarchalnej. Taki model reprezentowała polska rodzina szlachecka. $\mathrm{Z}$ trudnością poddawal się on liberalnym tendencjom tamtego stulecia. Wieś i rolnictwo traktowane były wówczas jako źródło niezależności, samowystarczalności oraz gwarancja zdrowia moralnego, zagrożonego przez nową cywilizację miejską. Trwanie części dworów i rodzin niemal wyłącznie w obrębie własnego środowiska oznaczało izolację, a co za tym idzie, odcięcie od szerszej wiedzy o kraju i świecie, od nowych idei i przenikających z zewnątrz wpływów nowoczesności ${ }^{24}$. Sprzyjająca utrzymywaniu się przestarzałego układu gospodarczo-społecznego atmosfera zapewniała ciągłość szlacheckiej mentalności, obyczajów i tradycyjnego modelu życia rodzinnego.

Model tradycyjnej rodziny chłopskiej trwał dłużej niż szlacheckiej. Był bowiem aktualny jeszcze w pierwszych dekadach XX wieku. Główne jej cechy stanowiły stałość, zwartość, ścisły wiązek z gospodarstwem - jedność rodziny i gospodarstwa, patriarchalizm oraz rygoryzm wzorców kulturowych, w tym regulujących podział pracy członków rodziny. Były one zarazem wzorcami wychowawczymi. Dzieci w rodzinach chłopskich były całkowicie podporządkowane ojcu, a wychowanie odbywało się w duchu zasad i wartości religijnych $^{25}$. Jednak w końcu XIX wieku w konfrontacji z nową cywiliza-

22 K. Jakubiak, Świat postulowanych wartości życia $i$ wychowania w rodzinach polskich na przetomie XIX i XX wieku, „Prace Naukowe Akademii im. Jana Długosza w Częstochowie. Seria: Pedagogika” 2012, z. 21, s. 380.

23 D. Markowska, Rodzina wiejska na Podlasiu 1864-1964, Wrocław 1970, s. 155.

24 M. Leśniakowska, Dwór polski a idee domu w kulturze europejskiej, w: Dwór polski w XIX wieku. Zjawisko historyczne i kulturowe, Warszawa 1990, s. 14.

25 Z. Jabłonowska, Rodzina w XIX i na poczatku XX wieku, w: Przemiany rodziny polskiej, red. J. Komorowska, Warszawa 1975, s. 52-71. 
cją miejską przeżywał się ówczesny ideał życia rodzinnego, związany $\mathrm{z}$ wsią i rolnictwem.

Rodziny mieszczańskie, często wywodzące się z zdeklasowanych sfer ziemiańskich, podtrzymywały w pierwszym i drugim pokoleniu tradycyjny model funkcjonowania rodziny. Zauważalne jednak już były różnice między tymi rodzinami, zajmującymi różną pozycje w stratyfikacji społecznej ${ }^{26}$. Miasto, przyciągając najczęściej z przyczyn materialnych nowych mieszkańców, niekiedy skazanych na długotrwałą rozłąkę z rodziną, sprzyjało osłabieniu jej spoistości, a niekiedy wykorzenieniu lub rozpadowi. Zjawisko to dotyczyło sproletaryzowanych rodzin z szlachecko-ziemiańskim rodowodem. Ówczesne przemiany, szczególnie widoczne w rodzinach robotniczych, objawiały się przede wszystkim wzrostem znaczenia rodziny dwupokoleniowej oraz zwiększaniem się grupy rodzin niepełnych, najczęściej pozbawionych ojca ${ }^{27}$.

Od schyłku XIX wieku nasiliła się tendencja, obecna głównie $\mathrm{w}$ środowiskach inteligenckich, do przyznawania dziecku ważnego miejsca $\mathrm{w}$ układzie rodzinnym, a $\mathrm{z}$ czasem stawało się ono postacią centralną. Tendencja ta przenikała do niższych warstw społecznych, a procesowi temu sprzyjał „Ruch Nowego Wychowania”, z jego pajdocentrycznymi postulatami poszanowania autonomii i indywidualności dziecka.

\section{Realizacja funkcii edukacyjnej w rodzinach polskich w XIX wieku}

Jak wskazywał przywoływany już Andrzej M. Tchorzewski, można założyć, że w toku realizacji funkcji edukacyjnej w rodzinie w jej życiu nie ma praktycznie działań, zachowań czy sytuacji, które byłyby wychowawczo obojętne dla dzieci. Wszystko bowiem, co się dzieje $\mathrm{w}$ rodzinie i z rodziną, oddziałuje na młode pokolenie. Oddziaływania te mają swoje źródło w całokształcie codziennego życia rodziny, są niejako wkomponowane w naturalne uczestnictwo w życiu rodziny. Można jednak oddziaływania te podzielić na dwa rodzaje -

26 A. Żanowska, Rodzina robotnicza w Warszawie na przetomie XIX $i$ XX wieku, „Kronika Warszawy” 1984, nr 2, s. 82-90.

27 M. Siennicka, Rodzina burżuazji warszarwskiej i jej obyczaj. Druga potowa XIX i poczqtek XX wieku, Warszawa 1998. 
zamierzone i mające określony cel, ale i niezamierzone, nieuświadamiane przez dorosłych, a mające znaczący wpływ na kształtowanie osobowości, postaw czy wiedzy dzieci ${ }^{28}$.

W analizowanym okresie edukację, wychowanie i wykształcenie domowe, określano jako wszystko to, co było związane z „rodziną i jej wpływem na dzieci”29. Rozumiane ono było jako całokształt poczynań mających dążyć do wykształcenia wszechstronnie rozwiniętego człowieka $\mathrm{i}$ - w aspekcie teoretycznym - dzielono je na poszczególne części: 1) fizyczne, mające na celu rozwinięcie ciała, utrzymanie zdrowia; 2) moralne, zmierzające do duchowego wykształcenia dziecka, kształtowania jego charakteru, serca i woli, wpajania prawd wiary i obowiązków względem Boga, siebie i bliźniego, a także 3) intelektualne, obejmujące rozwinięcie władz umysłowych, nabywanie talentów i pojęć estetycznych. By funkcja edukacyjna rodziny mogła być właściwie realizowana, rodzice i nauczyciele mieli w swych działaniach wychowawczych uwzględnić wszystkie te trzy wskazane aspekty.

Edukacja i wychowanie w rodzinie polskiej w XIX wieku, zależne od wielu złożonych czynników, przyjmowały jednak bardziej lub mniej sformalizowane formy. Nie zawsze procesy te miały charakter intencjonalny i świadomy, a ich przebieg nie we wszystkich przypadkach był w pełni zorganizowany, systematyczny oraz nie był pozbawiony wad, błędów. W edukacji i wychowaniu najmłodszych udział brali często wszyscy niemal członkowie rodziny: rodzice, dziadkowie, ciotki, wujkowie, rodzeństwo, w rodzinach zamożnych także rezydenci, najemne siły opiekuńcze i pedagogiczne - mamki, nianie, nauczyciele i nauczycielki domowe, a nawet służba. Wszystkie te osoby, intuicyjnie, nieświadomie lub intencjonalnie przekazywały dzieciom swoją wiedzę, poglądy, przekonania, systemy wartości, postawy i wzorce zachowań, realizując tym samym funkcję edukacyjną środowiska rodzinnego.

Przez cały wiek XIX (choć szczególnie w drugiej jego połowie i na początku wieku XX) publicyści pedagogiczni, moraliści, duchowni, higieniści formułowali szereg wskazówek i porad w zakresie edukacji dzieci i młodzieży, które publikowane były w postaci poradników

28 A.M. Tchorzewski, Edukacyjne funkcje rodziny, dz. cyt., s. 15.

29 E. Haufe, Dziecko i rodzina. Wskazówki ksztatcenia domowego dla matek, wolny przekład z niemieckiego, Warszawa 1892, s. 15. 
dla rodziców, artykułów w prasie rodzinnej, kobiecej i pedagogicznej, a także popularyzowane w formie odczytów czy wykładów otwartych. Wszystkie te inicjatywy podejmowane były w celu podniesienia kultury pedagogicznej rodziców, wychowawców, opiekunów i nauczycieli domowych i podkreślały znaczenie roli rodziny w edukacji, wychowaniu i kształceniu dzieci i młodzieży - nie tyle już intuicyjnej i przypadkowej, ale świadomej, zgodnej z najnowszymi zaleceniami nauk pedagogicznych, psychologicznych, medycznych, podporządkowanej przesłaniom aktualnych idei społecznych ${ }^{30}$. Podkreślić jednak należy, że wszystkie te publikacje miały ograniczony zasięg społeczny. Ich adresatami byli głównie czytelnicy z wyższych warstw, bowiem w warstwie robotniczej czy chłopskiej przeszkodą do sięgania po nie była często nieumiejętność czytania i wysoki koszt tego typu wydawnictw.

Bardzo często podkreślano szczególnie znaczącą rolę rodziców w organizacji domowego wychowania i kształcenia dzieci. Żądano od nich systematycznego przygotowywania się do tej roli, poczucia wagi obowiązku spełniania funkcji pedagogicznych. Powinnością rodziców było kierowanie wychowaniem i nauką dzieci, nadawanie kierunku wychowaniu fizycznemu, moralnemu, patriotycznemu, religijnemu, koordynowanie i organizowanie procesu nauczania, stwarzanie odpowiedniej atmosfery i warunków do nauki. Postulowano, by każdy rodzic zdobywał odpowiednią wiedzę dotyczącą kierowania i rozwijania umysłu i serca dziecka ${ }^{31}$.

Zob. np.: Ł. Kabzinska, Rodzina jako podstawowe środowisko wychowawcze w pedagogicznych koncepcjach Królestwa Polskiego z lat 1846-1914, w: Wychowanie w rodzinie polskiej od schytku XVIII do potowy XX wieku, dz. cyt., s. 139161; taż, Wychowawcza rola rodziny w opinii pozytywistów warszarskich, w: Wychowanie w rodzinie od starożytności po wiek XX, dz. cyt., s. 323-329; G. Michalski, Wskazania dla edukacji domowej w wybranym czasopiśmiennictwie polskim drugiej potowy XIX $i$ w pierwszych latach $X X$ wieku, w: $N a-$ uczanie domowe dzieci polskich od XVIII do XX wieku, dz. cyt., s. 91-100; K. Jakubiak, Popularyzacja wychowania rodzinnego dziecka w polskiej literaturze pedagogicznej i czasopismiennictwie XIX wieku, w: Rodzina w starożytnym Rzymie, red. J. Jundziłł, Bydgoszcz 1993, s. 269-275.

31 Zob. np.: J. Sobczak, Warunki i przejawy rozwoju teorii wychowania rodzinnego $i$ edukacji rodziców od czasów odrodzenia, w: Rodzina. Przesztość - teraźniejszośc - przysztość, red. A. Tchorzewski, Bydgoszcz 1988, s. 58-62; K. Jakubiak, Wypracowanie modelu wychowania rodzinnego dziecka w polskiej pedagogice XIX i poczatku XX wieku, w: Rodzina i wychowanie. Ciagtośc $i$ zmiennośc na przestrzeni wieków, red. J. Jundziłł, Bydgoszcz 1995, s. 121-139. 
Jak już podkreślano, szczególną rolę w edukacji dzieci w wieku XIX przypisywano matce. Ojciec najczęściej był w życiu rodzinnym nieobecny, zajęty walką o niepodległość kraju, pracą polityczną i zawodową, oddany gospodarstwu, rzemiosłu, przemysłowi lub innym zajęciom publicznym, matka zaś pozostająca $\mathrm{w}$ domu, przy rodzinnym ognisku, mająca stale u swego boku dzieci, miała największy wpływ na ich umysły i serca. Zgodnie ze wskazanym modelem matki -Polki, w jej ręku skupiała się troska o domowe ognisko, wpajanie młodemu pokoleniu tradycji i wartości narodowych, patriotyzmu, religijności. To zwykle matki - niezależnie od warstwy społecznej - uczyły swe dzieci mowy polskiej, abecadła, polskich wierszy, modlitw, historii Polski, pieśni patriotycznych i religijnych. Matki miały w dzieciach kształtować postawy moralne, ale też troszczyć się o czystość i zdrowie ciała. Niemal w każdym XIX-wiecznym pamiętniku można odnaleźć bardziej lub mniej rozbudowane fragmenty poświęcone matce. Bogata galeria wspomnień o matkach - Polkach ukazuje je zwykle jako opiekunki rodziny, oddane dzieciom, mężowi, Ojczyźnie ${ }^{32}$. Feliks Kon wspominał: „[...] na straży tradycji stały kobiety - matki Polki, o których Wincenty Pol mówi: «Jeszcze wykarmią one w zaciszy grono olbrzymiej młodzieży, od nich pachole o nas usłyszy

32 Doskonale oddają to słowa Józefa Dowbora Muśnickiego, który w swych wspomnieniach pisał: „Kiedy już zdołałem nabrać większej praktyki życiowej, doszedłem do przekonania, że wszelkie zakusy rusyfikacyjne i germanizatorskie rozbijały się o zasady, wpajane w nasze dusze i serca przez polską kobietę - nasze matki, siostry, nauczycielki. Polka okazała się silniejsza od Bismarcka i Pobiedonoscewa, wraz z całym ich aparatem państwowym i olbrzymimi środkami wynaradawiania. Rola mężczyzn w tej walce była do pewnego stopnia drugorzędna. Byliśmy niejako jakby narzędziem w ręku kobiety, która swoją siłę czerpała z wiary w sprawiedliwość dziejową i nauki Kościoła”. J.D. Muśnicki, Moje wspomnienia, Warszawa 1935, s. 24. Zbigniew Drzewicki pisał: „Były to czasy ucisku rusyfikacyjnego. Dom moich rodziców był całkowicie oddany kultowi polskości. To moja matka wtajemniczała mnie w kształty liter, cyfr i układ zdań rodzimej mowy”. Z. Drzewiecki, Wspomnienia muzyka, Kraków 1971, s. 12. Podobnie o roli matki w nauce domowej pisała Maria Witkiewiczówna: „Matka sama uczyła młodsze dziewczynki [...] przy każdej lekcji mówiła nam, że będąc wielkim narodem, jesteśmy w niewoli. Ucząc miłości bliźniego, nie wahała się powiedzieć, że wroga Moskala nie trzeba kochać. Nie szło to w parze z jej złotym sercem, ale patriotyzm górował nad wszystkim”. M. Witkiewiczówna, Wspomnienia o Stanistawie Witkiewiczu, Warszawa 1936, s. 8. 
i jak my w wolność uwierzy». Rzeczywiście, polskie matki święcie wypełniały te misję"33.

W XIX wieku w publicystyce pedagogicznej i rodzinnej przypominano o obowiązku korygowania w domu braków i niedostatków lub tendencyjności nauczania szkolnego, postulując jednocześnie dwutorowość kształcenia: oficjalnego w szkole, najczęściej publicznej (rządowej), i prywatnego $w$ domu rodzinnym ${ }^{34}$. Zamożne rodziny arystokratyczne, szlachecko-ziemiańskie, bogate i średniozamożne rodziny mieszczańskie kształciły więc swoje dzieci w domach. Systematycznej nauki domowej nie organizowały rodziny robotnicze i chłopskie (w tych typach rodzin nauczanie przybierało formy niezorganizowane, ograniczając się do nauki czytania i pisania, samouctwa, bądź od połowy wieku XIX przyjmując formy tajnej oświaty ludowej). W popularyzowanej wówczas przez publicystów edukacji domowej dzieci brali udział niemal wszyscy członkowie rodziny, łącznie z dziadkami, rezydentami oraz osoby celowo zatrudniane: nianie, bony i nauczyciele domowi. Rodzicom zalecano ustalenie z domowym nauczycielem wszystkich kwestii związanych $z$ doborem przedmiotów i metod nauczania ${ }^{35}$.

Do głównych przyczyn organizowania dzieciom nauki domowej zaliczyć można obronę dzieci przed rusyfikacją i germanizacją, jednak było ich znacznie więcej: niechęć rodziców przed kontaktem ze szkolnymi, często niżej urodzonymi kolegami, oszczędność (zatrudnienie nauczycielki było tańsze niż koszty nauki w mieście), znaczną odległość od szkoły elementarnej i niski poziom jej kształcenia. Przyczyną organizacji domowej nauki na poziomie średnim, oprócz

F. Kon, Narodziny wieku. Wspomnienia, Warszawa 1969, s. 14.

Potwierdzają to słowa pamiętnikarki, Zofii Iwanickiej: „Zadaniem domu rodzinnego, a przede wszystkim matki, była nauka dziejów ojczystych, niezafałszowanych, a także literatury polskiej, czarującej pięknem języka i poezji. Tak umocnieni na duchu, mając mocne podstawy prawdziwej wiedzy o Polsce, z wiarą niezłomną, że naród kiedyś powstanie z niewoli i właśnie na nas się oprze, szliśmy do szkoły rosyjskiej. Braliśmy z niej wiedzę ogólną, ale nigdy nie zdradziliśmy Polski”. Z. Iwanicka, Pamiętnik, w: W. Rodowicz, S. Rodowiczowa, Zofia z Rodowiczów Iwanicka, Tryptyk rodzinny, Warszawa 1999, s. 62.

35 M. Nawrot-Borowska, Nauczanie domowe na ziemiach polskich w II potowie $X I X$ i na poczqtku XX wieku - zapatrywania teoretyczne i praktyka, dz. cyt., s. 91-98. 
chęci uniknięcia wpływów szkoły zaborczej, był fakt zbyt dużej liczby kandydatów chcących kształcić się w gimnazjach czy choroba dziecka uniemożliwiająca szkolną edukację ${ }^{36}$.

Specyfika i organizacja nauki domowej zależna była od płci i wieku dziecka. Szczególną wagę przywiązywano do kształcenia chłopców, którzy stanowić mieli o przyszłości kraju, sprawować urzędy, przejmować majątki i być kontynuatorami rodów. Dla nich edukacja domowa stanowiła więc przygotowanie do podjęcia dalszej nauki w szkołach. Dziewczęta, w niemal całym badanym okresie, często rozpoczynały i kończyły zdobywanie wiedzy w domu. $\mathrm{Z}$ biegiem dziesięcioleci jednak edukacja domowa miała dawać im już nie tylko ogólną ogładę, dobre maniery i znajomość talentów, ale w ostatnich dekadach wieku XIX przygotowywała do szkół - pensji żeńskich czy publicznych szkół średnich. Dla dzieci od 3. do 7. roku życia zatrudniano bony, które oprócz udzielania podstaw wiedzy o otaczającym świecie i opieki nad dzieckiem nauczać miały języków obcych - francuskiego, angielskiego, niemieckiego. Po ukończeniu 7-8 lat dzieci rozpoczynały nowy etap edukacji domowej, bardziej intensywny i o rozszerzonym programie nauczania. Celem domowej nauki elementarnej miało być wszechstronne rozwinięcie władz dziecka umysłowych, fizycznych i moralnych, a przede wszystkim udzielenie mu podstaw nauk do dalszego kształcenia ogólnego czy specjalnego. Lekcje prowadzono regularnie, codzienne, z wyjątkiem niedziel i świąt, często obowiązywał rygor szkolny, odpytywanie, sprawdziany wiadomości, a raz na jakiś czas dziecko zdawało także egzaminy z postępów w nauce. Kurs nauk początkowych trwał zwykle trzy lata, od 7 do 10 roku życia dziecka i obejmował język ojczysty, języki obce, arytmetykę, początki historii krajowej, wiadomości o ziemi i świecie, słońcu, księżycu, gwiazdach, meteorologii, o zwierzętach i roślinach krajowych. Nie należało także zapominać o zapoznawaniu dzieci z pracami domowymi, gospodarskimi, ogrodniczymi, leśnymi (na wsi), zawodami związanymi z handlem i rzemiosłem, przemysłem, technologią (w mieście). W niektórych domach dzieci młodsze zaczynały edukację elementarną u boku matki, starszej siostry lub innej osoby z najbliższej rodziny. W wielu rodzinach jednak nauka początkowa rozpoczynała się pod kierunkiem bony lub guwernantki,

Tamże, s. 99-108. 
w innych zaś zwykle dopiero po kilku latach pracy matki z dziećmi szukano dobrych i zdolnych nauczycieli, którzy uczyli profesjonalnie starsze już dzieci, przygotowując je do egzaminów do szkół gimnazjalnych. Niekiedy też początkowe klasy szkoły średniej realizowano trybem nauki domowej ${ }^{37}$. Nawet gdy dzieci uczęszczały do szkół publicznych, nauka domowa była nadal organizowana. Po ukończeniu lekcji w szkole dzieci pobierały dodatkowe domowe lekcje z zakresu języków obcych, a także historii i literatury ojczystej. Często rozwijano także osobiste talenty uczniów (szczególnie w przypadku dziewcząt $)^{38}$.

Podczas gdy dzieci z warstw wyższych edukowały się w domu, otoczone nianiami, bonami i guwernantkami, dzieci z rodzin uboższych - chłopskich czy robotniczych - uczyły się pracy, obowiązków i pomocy w utrzymaniu domowego gospodarstwa i poprawy bytu materialnego rodziny. $\mathrm{Na}$ wsi już kilkuletnie dzieci pracowały, wyręczając dorosłych w części obowiązków ${ }^{39}$. Dziewczęta opiekowały się młodszym rodzeństwem, pomagały matce $\mathrm{w}$ prowadzeniu gospodarstwa domowego (gotowanie, pranie, porządki), pilnowały drobiu. Chłopcy przyuczali się do obowiązków gospodarskich przy

37 Edward Ligocki wspominał: „Kurs pierwszych klas gimnazjalnych przechodziłem w domu. Rodzice moi postanowili oddać mnie jak najpóźniej do szkół. Uważany był wówczas za koszmar obowiązujący podręcznik Iłowajskiego, carosławnego pseudohistoryka, deformujący w sposób dotkliwy aspekt stosunków polsko-rosyjskich, toteż kładziono w domu szczególniejszy nacisk na historię Polski, chcąc mnie uodpornić na niepożądane wkręty i chwyty w naświetlaniu przeszłości”. E. Ligocki, Dialog z przeszłościq, Warszawa 1970, s. 18. „Reżim rosyjski kazał Polakom na polskiej ziemi uczyć się języka polskiego po rosyjsku. [...] Miało to ten skutek, że młodzież polska uczyła się języka polskiego, historii literatury i dziejów ojczystych poza szkołą urzędową, na tajnych kompletach i u prywatnych nauczycieli”. A. Wierzbicki, Żywy Lewiatan, Warszawa 2001, s. 41.

38 Henryk Fukier pisał: „Wcześnie rozpocząłem naukę w szkołach, pogłębioną dokształcaniem w domu, zarówno w językach obcych, jak i w języku polskim, historii i literaturze i muzyce". H. Fukier, Wspomnienia staromiejskie, Warszawa 1973, s. 67.

39 „Dziecko chłopskie - jak pisał pamiętnikarz Jan Szczepański - zaczynało pracować wcześniej, niż poszło z tabliczką i rysikiem do szkoły. Praca była jego pierwszą szkołą, i to ciężką pracą, za która ponosiło się pełną odpowiedzialność i od samego początku życia uczyło się odpowiedzialności za siebie, za rezultaty pracy”. J. Szczepański, Korzeniami wrostem w ziemię, Katowice 1984, s. 34. 
ojcu, pasali bydło i konie. Byt dziecka podporządkowany był trwaniu rodziny i jej funkcjonowaniu, zaś pozycja dziecka w rodzinie zależała zaś od jego przydatności w pracach gospodarskich. Rodzice, realizując funkcję edukacyjną, czynili to niejednokrotnie nie szczędząc dzieciom kar fizycznych i połajanek. Wychowanie na wsi bowiem $\mathrm{z}$ reguły było rygorystyczne i surowe, a dzieci obowiązywało bezwzględne posłuszeństwo wobec rodziców, szczególnie zaś ojca ${ }^{40}$. Model ten obecny był też w rodzinach robotniczych czy rzemieślniczych. Dzieci robotnicze często pracowały od najmłodszych lat za niewielkie wynagrodzenie, zaś wychowawczy wpływ rodziny kończył się w zasadzie w chwili, kiedy stawały się one wystarczająco dorosłe do podjęcia obowiązku pracy zarobkowej. Sytuacji takiej sprzyjał brak uregulowań prawnych dotyczących pracy nieletnich. Podobnie w rodzinach rzemieślniczych, surowej atmosferze wychowawczej domu rodzinnego towarzyszyło możliwie szybkie wdrażanie do pracy i nauki zawodu. Trudne warunki życiowe i mieszkaniowe robotników czy rzemieślników w mieście powodowały, że w niewielkich pomieszczeniach przebywało wiele osób, często lokatorów, a dzieci były świadkami różnorodnych zachowań, nie zawsze przyzwoitych czy moralnych. Plagą społeczną wśród niższych warstw społecznych było pijaństwo ${ }^{41}$. Funkcja edukacyjna rodziny w tym wypadku znacząco odbiegała od postulowanych ideałów wychowawczych głoszonych przez pedagogów i moralistów.

„Nawet już dorastające dzieci miały respekt i poszanowanie dla rodziców, szczególnie zaś dla ojca. Ten zaś nigdy nie żartował, za każde uchybienie wysmarował rzemiennym pasem. [...] Nieraz dostało się przy tej sposobności i matce, gdy podnieciwszy ojca, raptem się zmieniła, stając w obronie bitych dzieci. Rzadko bardzo się zdarzało, by nawet niewinnie krzywdzony syn rzucił się na ojca albo nawet starał się chwycić kij, którym był bity”. W. Witos, Moje wspomnienia, Warszawa 1878, s. 40. „Wszyscy w domu bez szemrania uginali się pod surowością ojca. [...] Skutki gniewu ojca odczuwałam nieraz [...] bałem się go wówczas jak ognia, aż do nienawiści" - pisał Julian Fałat. J. Fałat, Pamiętniki, Katowice 1987, s. 17, 34-35. Por. W. Mędrzecki, Intymnośc i sfera prywatna w życiu codziennym i obyczajach rodziny wiejskiej w XIX i pierwszej potowie XIX wieku, w: Rodzina - prywatność intymnośc, dz. cyt., s. 108; Dzieciństwo w rodzinach plebejskich, w: W. Korzeniowska, Edukacja i wychowanie różnych warstw spotecznych na ziemiach polskich od drugiej potowy wieku XIX do roku 1918, Kraków 2004; Narodziny $i$ wiek dziecięcy, w: B. Baranowski, Życie codzienne wsi między Wartq a Pilica w XIX wieku, Warszawa 1969.

41 D. Kałwa, Polska doby rozbiorów i międzywojenna, dz. cyt., s. 260. 
Niezwykle istotnym przejawem realizacji funkcji edukacyjnej rodziny polskiej w XIX wieku było kształtowanie w młodym pokoleniu patriotyzmu. Naród bowiem zachowuje swą trwałość i tożsamość dzięki wielu różnorodnym czynnikom, do których z całą pewnością zaliczyć można także rodzinę. W czasie bytowania narodu bez państwa, jakim był okres zaborów, rodzina odegrała istotną rolę w utrzymaniu tożsamości narodowej. Kultywowane w polskich rodzinach codzienne i świąteczne rytuały, zachowania, normy, tradycje i obyczaje stały się istotną składową owej tożsamości.

W pierwszym rzędzie patriotyzm dzieci kształtowała specyficzna atmosfera polskich domów - pałaców, dworów czy mieszkań w mieszczańskich kamienicach, a nawet chłopskich chat. W znacznej części tych domów panowała atmosfera narodowa, połączona ze szczerym entuzjazmem dla polskiej literatury, sztuki i nauki. Rodzice starali się wychowywać dzieci duchu patriotyzmu, w poszanowaniu pracy dla ojczyzny, w ideałach katolickich i narodowych, starając się usilnie o naukę polską - w polskim języku i z zakresu przedmiotów dotyczących spraw narodowych. Każdy więc polski dom, w którym kultywowano tradycje polskie i dbano o utrzymanie polskiej narodowości, stawał się ostoją polskości ${ }^{42}$. Wiele było sposobów budzenia uczuć patriotycznych w młodym pokoleniu. Należały do nich np. kultywowanie tradycji przodków, którzy walczyli w walkach narodowowyzwoleńczych (począwszy od konfederacji barskiej, kampanii napoleońskich po powstanie styczniowe z 1863 roku), opowieści z dziejów rodziny, walk i wojen o wolność kraju (opowiadali je rodzice, dziadkowie, często sami wcześniej biorący w nich udział, a także byli powstańcy i uczestnicy walk, rezydenci dworów), odwiedzanie

42 Należy tu podkreślić, iż życie ówczesnych Polaków we wszystkich trzech zaborach toczyło się dwoma torami. Oprócz gorących patriotów byli także i tacy, którzy swe szczęście upatrywali w podporządkowaniu się wrogowi, co zapewniało im spokojne życie, a nawet ulgi ze strony władz zaborczych. Patriotyczny więc model wychowania rodzinnego nie był realizowany przez wszystkie polskie rodziny. Skutkiem tego nie można bezkrytycznie przyjmować powszechnie przyjętej opinii, iż polski dom rodzinny w obliczu prześladowań i niewoli narodowej był jedyną twierdzą polskości oraz ośrodkiem wychowania patriotycznego i narodowego młodego pokolenia Polaków. Por. M. Nawrot-Borowska, Edukacja patriotyczna w rodzinach polskich w II potowie XIX i na poczatku XX wieku w świetle literatury pamiętnikarskiej, w: Niepodlegtość $i$ wychowanie: z doświadczeń II Rzeczypospolitej, red. W. Jamrożek, E. Kula, M. Pękowska, Kielce 2012, s. 125-178. 
mogił poległych za wolność Polski, wycieczki w miejsca potyczek, walk narodowowyzwoleńczych, otaczanie czcią i szacunkiem pamiątek po przodkach, uczestnictwo w mszach i nabożeństwach za ojczyznę. Silnie działały też na wyobraźnię dziecięcą i rozbudzanie umiłowania polskości obrazy, reprodukcje i ryciny o treści patriotycznej - z wizerunkami przodków, bohaterów narodowych, królów polskich, czytywanie utworów literatury polskiej, wspólne, rodzinne muzykowanie, gdzie oprócz śpiewu pieśni patriotycznych grywano też utwory wybitnych polskich kompozytorów. W rodzinach odbywały się tajne obchody rocznic powstań narodowych, konstytucji trzeciomajowej, urodzin i zgonów wieszczów. Przybierały one formę domowych, patriotycznych przedstawień amatorskich, a towarzyszyły im przeważnie żywe obrazy. Na przedstawienia składały się deklamacje wierszy patriotycznych, piosenki, utwory fortepianowe, komedyjki, monologi, dialogi itp., odgrywane niejednokrotnie przez najmłodszych członków rodzin. Te przejawy funkcji edukacyjnej dotyczyły jednak głównie rodzin zamożnych, inteligenckich. W grupie ludności wiejskiej dopiero w okresie popowstaniowym, u schyłku XIX wieku można mówić o kształtowaniu się świadomości historycznej, narodowej ${ }^{43}$. Koniec XIX i początek XX wieku były okresem intensywnej działalności uświadamiającej chłopów pod względem narodowym ${ }^{44}$. Jednak i w środowisku wiejskim żyła pamięć o insurekcji kościuszkowskiej, Tadeuszu Kościuszce czy Bartoszu Głowackim, a dzieci chętnie słuchały opowieści z dziejów walk i o bohaterach narodowych. Potwierdzenie znaczenia domu rodzinnego w edukacji patriotycznej młodego pokolenia znajdujemy w wielu przekazach pamiętnikarskich, których autorzy pochodzili ze wszystkich warstw społecznych ${ }^{45}$.

Zob. np.: H. Brodowska, Chtopi o sobie i Polsce. Rozwój świadomości spoteczno-narodowej, Warszawa 1984; K. Dunin-Wąsowicz, Świadomość narodowa chtopów w świetle pamiętników w okresie porwstań narodowowyzwoleńczych, „Acta Universitatis Lodziensis. Folia Historica” 1992, nr 45, s. 87-93.

44 Stanisław Pigoń pisał: „Świadomości narodowej z domu nie wyniosłem, nie mogłem wynieść. Ojciec jej nie miał, jak żaden z jego rówieśników [...]. Szkoła ówczesna, szkółka wiejska z końca XIX wieku też przecież narodowością nie tchnęła”. S. Pigoń, Z Komborni w świat. Wspomnienia mtodości, Warszawa 1983, s. 158-160.

45 Feliks Kon, pochodzący z zaboru rosyjskiego, pisał: „Ogniem i mieczem, szubienicami i katorgą ujarzmiła Rosja carska zbuntowaną Polskę [...]. Ale to, co działo się wewnątrz tych domów, było ukryte przed oczyma wrogów. Tam 
Praktykowane w zamożnych rodzinach przez domowników sposoby wychowania patriotycznego $\mathrm{w}$ istotny sposób wspomagane były wychowaniem religijnym ${ }^{46}$. Patriotyzm i religijność bowiem w badanym okresie przenikały się wzajemnie. Aby być patriotą w ówczesnych czasach, należało być także człowiekiem zaangażowanym religijnie. Kto kochał ojczyznę, powinien również kochać Boga. Jednak niezależnie od warstwy społecznej, religia stanowiła istotny czynnik wychowawczy, wpływała na obyczajowość, moralność i organizację życia rodzinnego. Szczególnie widoczne było to w przypadku środowiska wiejskiego, gdzie rok pracy zorganizowany był według kalendarza kościelnego, a życie podporządkowane wpajanym z dziada pradziada przez Kościól katolicki prawdom wiary, którym towarzyszyła rozbudowana obrzędowośćc ${ }^{47}$. Powszechnie jednak podkreślano wychowawczą wagę uczonej przez matkę pierwszej modlitwy w języku polskim, wspólne, rodzinne śpiewanie pieśni religijnych, czytywanie Biblii czy żywotów świętych. W zdecydowanej większości rodzin polskich regularnie odbywano domowe nabożeństwa, np. październikowe różańcowe czy majowe, poświęcone Maryi, lub czerwcowe Sercu Jezusowemu, a często podczas codziennych modlitw odmawia-

właśnie wzrastała i krzepła nowa, młoda Polska. Tam wzrastały dzieci, które zanim jeszcze nauczyły się pacierza, umiały już na pamięć hymny patriotyczne. Wzrastała młodzież, dla której przywieziony potajemnie z Galicji portret Kościuszki był większą świętością niż święte obrazy, a nawet krucyfiks”. F. Kon, Narodziny wieku. Wspomnienia, Warszawa 1969, s. 15. „Głęboko patriotyczny nastrój, jaki panowały domu moich rodziców, istniał, z bardzo nielicznymi wyjątkami wśród całej inteligencji, we wszystkich domach lekarzy, adwokatów, rejentów, literatów, pracowników bankowych, urzędników [...]. Dom rodzinny inteligenta polskiego był ściśle zamknięty dla wszystkich rosyjskich wpływów [...]. Poza progiem polskiej rodziny inteligenckiej, zarówno ziemiańskiej, jak mieszczańskiej istniała tylko polska myśl, polska praca, polska cywilizacja. Jedynie arystokracja nasza utrzymywała towarzyskie stosunki z dygnitarzami carskimi”. S. Grabski, Pamiętniki, Warszawa 1989, s. 24-25; Arka Bożek, Ślązak, z pochodzenia chłop, wspominał: „W domu u nas, który był prawdziwym ośrodkiem polityki w naszej wsi, mówiło się bardzo dużo na temat zagadnień narodowych [...]. Byłem jeszcze dzieckiem, lecz przeżywałem to wszystko”. A. Bożek, Pamiętniki, Katowice 1957, s. 48. Zob. M. Nawrot-Borowska, Edukacja patriotyczna w rodzinach polskich w II potowie XIX i na poczatku XX wieku w świetle literatury pamiętnikarskiej, dz. cyt., s. 125-178.

46 A. Szarkowska, Wychowanie religijne w rodzinie polskiej w okresie zaborów, „Kultura i Edukacja” 2003, nr 3/4, s. 127-131.

47 D. Kaława, Polska doby rozbiorów i międzywojenna, dz. cyt., s. 234-235. 
no jedną, specjalną modlitwę w intencji Polski i jej niepodległości. Zarówno w wiejskich chatach, jak i ziemiańskich dworkach czy mieszkaniach w miejskich kamienicach było mnóstwo symboli religijnych, ołtarzyków, krzyży, obrazów o treści religijnej, w których cudowną moc wierzono i do których modlono się całymi rodzinami w najróżniejszych intencjach, chwilach zagrożenia czy nieszczęścia. Również całe rodziny udawały się na niedzielną mszę świętą, a budynek kościoła i wspólna modlitwa łączyła rodziny z rożnych grup społecznych. Szczególnie istotnym dla polskich rodzin był kult maryjny. Również pielgrzymki do „miejsc świętych”, sanktuariów były w XIX wieku popularną formą wyznawania przywiązania do wiary i religii, jednocześnie bywały też przejawem tożsamości narodowej ${ }^{48}$. Wychowawcze znaczenie miało także rodzinne przeżywanie okresów świątecznych - szczególnie Bożego Narodzenia i Wielkanocy, ze wszystkimi charakterystycznymi dla nich tradycjami i zwyczajami. Choć długie celebracje, modlitwy i nabożeństwa, były zwykle dla najmłodszych uciążliwe, to stanowiły ważny element edukacji - włączały dzieci w wielowiekową tradycję religijną narodu polskiego, w kultywowanie obyczajów kultury religijnej i narodowej ${ }^{49}$.

48 Marianna Jasiecka tak wspominała pielgrzymkę do Częstochowy, na którą zabrała swoje dzieci: „Z jakiem wzruszeniem każdy spogląda już z daleka na wieżę jasnogórskiej świątyni! Róża i Zosia były naprawdę głęboko przejęte widokiem klasztoru, przypominały sobie bez przerwy opisy Jasnej Góry w Potopie naszego mistrza literatury - Henryka Sienkiewicza. Uroczyste nabożeństwo, widok cudownego obrazu Patronki naszej ojczyzny na zawsze zapadają w serce”. J. Fedorowicz, J. Konopińska, Marianna i róże. Życie codzienne w Wielkopolsce w latach 1889-1914 w tradycji rodzinnej, Poznań 1995, s. 161. Zob. np. M. Wójcik, Znaczenie wychowawcze pielgrzymek rodzin górnoślaskich do miejsc kultu narodowego w latach 1896-1914, w: Rodzina jako środowisko wychowawcze w czasach nowożytnych, dz. cyt., s. 158-166.

49 Kazimierz Jaroszyk, pochodzący z poznańskiej rodziny robotniczej, wspominając wpływy, które odegrały najważniejszą rolę w jego życiu, wskazał na wychowanie narodowe i religijne: „Jako dziecko wychowany po polsku, umiałem czytać i pisać, a pruska szkoła okropnie na mnie oddziałała [...]. Odebrałem w domu szczere katolickie wychowanie. Jako dziecko uczęszczałem w niedziele i święta do kościoła nie tylko, przed ale i po południu. Codziennie odmawiałem długie pacierze, wstępowałem do kościoła przed nauką szkolną, śpiewałem z rodzicami w domu pieśni religijne”. J. Chłosta, Kazimierz Jaroszyk 1878-1941. O narodowy ksztatt Warmii i Mazur, Olsztyn 1986, s. 22. 
Zadaniem edukacyjnym rodziny było kształtowanie w młodym pokoleniu systemu wartości moralnych. $Z$ analiz źródeł pamiętnikarskich wynika, że młode pokolenie podstawowe wartości przejmowało od rodziców i dziadków. Skala wartości starszego pokolenia w rodzinach ziemiańskich i włościańskich opierała się na trzech kategoriach: rodzinie, pracy i wierze. Pokolenie dzieci, szczególnie w przededniu odzyskania niepodległości, wyraźnie już artykułowało swój system wartości, w którym nauka szkolna wyprzedzała pracę, której już nie pojmowano jako kategorii samoistnej ${ }^{50}$. Zdaniem ówczesnych pedagogów, środowisko rodzinne miało służyć przekazywaniu tych zwłaszcza wartości, których dziecko polskie nie było w stanie odnaleźć w szkole publicznej (rządowej). Tę ostatnią jednak akceptowano, bo wykształcenie ceniono coraz bardziej powszechnie. Wśród wspomnianych tu ogólnikowo wartości wymieniano między innymi miłość kraju ojczystego, podporządkowanie własnych potrzeb i interesów interesowi narodu, a także szereg cnót osobistych ${ }^{51}$ : poczucie sprawiedliwości, uczciwości, szacunek dla bliźnich (także niżej urodzonych i zwierząt), prawdomówność. Cnoty te należało kształtować najlepiej drogą przykładu osobistego, dlatego też rodzice i domownicy dbać powinni o swoje zachowanie w obecności dzieci. Należało też - szczególnie w rodzinach warstw wyższych - zwracać uwagę na dobór służby, piastunek, bon, nauczycieli domowych, by stanowili oni wzór moralności dla wychowanków. Także staranny dobór lektury oraz towarzystwa do zabaw miały być gwarancją czystości serca i duszy dziecka.

Podejmując kwestie moralności w rodzinie, warto zwrócić uwagę na problem wychowania seksualnego, rzadko dotąd eksponowany $\mathrm{w}$ badaniach historyczno-pedagogicznych. W tym aspekcie

50 A. Denisiuk, $W$ poszukiwaniu nowej formuty dla dawnych kryteriów wartosci. Dylematy wychowania w rodzinie na Pomorzu w drugiej potowie XIX i na początku XX stulecia, w: Rodzina jako środowisko wychowawcze, red. K. Jakubiak, Bydgoszcz 1995, s. 129. Franciszek Zabielski wspominał: „Trzeba być skromnym i posłusznym. Trzeba mieć szacunek dla starszych. Złych ludzi omijać z daleka. Rano i wieczorem odmawiać paciorek. Trzeba żegnać się przed jedzeniem, po jedzeniu i od wszelakich złych pokus. Trzeba być grzecznym i kochać bliźniego, bo Pan Bóg powiedział: «Kochaj bliźniego, jak siebie samego»", w: F. Zabielski, Z życia i z pamięci, Warszawa 1980 s. 70.

51 M. i L. Trzeciakowscy, $W$ dzierwiętnastowiecznym Poznaniu, Poznań 1987, s. $269-270$. 
realizacja funkcji edukacyjnej w rodzinie polegać miała w głównej mierze - w myśl zaleceń coraz liczniej pojawiających się, szczególnie w II połowie XIX wieku poradników z zakresu medycyny i higieny oraz seksualności człowieka (adresowanych głównie do wyższych warstw społecznych) - na wychowaniu dziecka w czystości, chronieniu od wszelkich pokus cielesnych i wykroczeń przeciwko moralności płciowej, zapobieganiu przedwczesnemu rozbudzeniu życia płciowego oraz onanizmowi, a także uświadomieniu płciowym i przekazaniu wiedzy o pochodzeniu człowieka. W praktyce zwykle jednak ograniczano się do ochrony dziecka przed zepsuciem, bardzo rzadko podejmując tematy związane $z$ dojrzewaniem, seksualnością i prokreacją. Wokół zagadnień seksualnych wytworzyła się w omawianym okresie we wszystkich warstwach społecznych atmosfera tajemnicy i swoistego tabu. Myślenie i mówienie o „tych sprawach” wywoływało zwykle uczucie wstydu i zażenowania wśród dorosłych, którzy często nie radzili sobie wychowaniem seksualnym dzieci52. Izabela Moszczeńska, jedna $\mathrm{z}$ czołowych propagatorek wychowania seksualnego w rodzinie, trafnie oddała specyfikę tego aspektu edukacji dzieci w badanym okresie nazywając ją „tajną stroną życia i wychowania [...], o której się przez przyzwoitość milczy, a przez lekkomyślność zapomina" ${ }^{33}$. I jak czytamy we wspomnieniach, zdecydowana większość rodziców miała takie właśnie przekonanie w kwestii uświadomienia seksualnego swoich potomków, starając się unikać jakichkolwiek rozmów na ten temat, a przejawy zainteresowania seksualnością traktując w kategoriach grzechu nieczystości ${ }^{54}$.

52 M. Nawrot-Borowska, Sprawy tajemne i nieczyste. Rola rodziny w wychowaniu seksualnym dzieci w drugiej potowie XIX i na początku XX wieku w swietle poradników. Zarys problematyki, w: Wychowanie w rodzinie. Od starożytnej myśli filozoficznej do wspótczesnych rozwiązań legislacyjnych, dz. cyt., s. 127-162; W. Mędrzecki, Intymność i sfera prywatna życiu codziennym i obyczajach rodziny wiejskiej w XIX i pierwszej potowie wieku, dz. cyt. s. 115.

53 Czego nie wiemy o naszych synach? Fakta i cyfry dla u̇̇ytku rodziców oświetlita I. Moszczeńska, Warszawa 1904, s. 14.

54 Władysław Jan Grabski wspominał: „Rodzice moi, polegając, jakże zawodnie, na prawidłowym wpływie szkoły, czyli kolegów i religii czy katechety, nie zajmowali się naszym uświadomieniem”. W.J. Grabski, Blizny dzieciństwa, Warszawa 1971, s. 154. „W tamtych czasach dorośli na takie pytania zwykli odpowiadać mętnym wykładem biologii bez pointy”. S. Hartman, Wspomnienia lwowskie i inne, Wrocław 1994, s. 9. „Jeżeli mi w domu tego nie mówiono, to widocznie mówić o tym bez potrzeby jest nieobyczajnie. 
Jak wyraźnie podkreślano w publikacjach pedagogicznych badanego okresu, warunkiem zdrowej duszy i umysłu dziecka miało być zdrowe ciało. Już przed poczęciem małżonkowie mieli zwrócić uwagę na swój stan zdrowia, mający być podstawą przyszłego zdrowia dziecka. Kobieta brzemienna miała dbać o higieniczny styl życia, zaś po narodzinach karmić samodzielnie piersią. By dziecko zdrowo rosło, należało zapewnić mu odpowiednie odżywianie, adekwatny do pory roku i pogody ubiór, dbać o czystość ciała i odpowiednią dawkę ruchu na świeżym powietrzu. Troska o higienę i zdrowie w rodzinie miała być gwarantem rozwoju zdrowego społeczeństwa. I choć w I połowie XIX wieku często praktykowano jeszcze tzw. wychowanie cieplarniane, to w kolejnych dekadach, dzięki popularyzacji zasad higieny, coraz częściej w rodzinach zwracano uwagę na racjonalne wychowanie fizyczne dzieci, właściwe odżywianie, hartowanie, urządzano domowe gimnastyki, posyłano dzieci do ogrodów i parków, w których organizowano zabawy i gry sportowe $\mathrm{e}^{55}$. Powyższe ustalenia odnoszą się do rodzin z wyższych sfer - dzieci z niższych sfer przychodziły na

Rodzice przecie i tak wiedzieli, że się o tym podowiaduję, ale woleli, aby to się stało w swoim czasie, po prostu w toku poznawania życia i świata a może z nauki przyrody, niż przez uroczyste wtajemniczenia”. M. Pawlikowski, Pamiętniki. Medyka - Kraków - Zakopane, Kraków 1998, s. 56. Konrad Górski wspominał, że na zadane matce pytanie skąd się bierze dziecko, ta nie potrafiła odpowiedzieć. „Dała mi na poczekaniu odpowiedź wymyśloną i nieprzekonywującą. Dodała, że jak będę starszy, to się o tym dowiem i zrozumiem. Ale nigdy więcej nie przyszło do żadnej rozmowy na ten temat”. K. Górski, Pamiętniki. Z rękopisu, z upoważnienia autora opracował, zredagował i posłowiem opatrzył Z. Jędrzyński, Torun 1995, s. 37.

„W atmosferze hartownej rodzice nas wychowali, ubierano nas czysto, ale bardzo skromnie, nie dawano żadnych specjalnych przysmaków, lecz kazano jeść, co przeznaczone było. O kaprysach nie było mowy”. E. Raczyński, Rogalin i jego mieszkańcy, Poznań 1991, s. 55. „Nasze nowe ubranka to kostiumy gimnastyczne - pisała Helena Duninówna - Idziemy oto na stałą godzinę gimnastyki do zakładu panny Heleny Kuczalskiej”. Kufer Kasyldy czyli wspomnienia z lat dziewczęcych. Wybór pamiętników z XVIII i XIX wieku, oprac. D. Stępniewska, B. Walczyna, Warszawa 1983, s. 340. Julian Brun-Bronowicz wspominał, iż w pokoju dziecinnym chłopcy mieli wiele rozmaitych przyrządów gimnastycznych, jak trapez, lina do sufitu, rapiery i maski do fechtunku. Dzieci codziennie uprawiały poranną gimnastykę, a w lecie przy każdej okazji pływały i nurkowały w Wiśle. Por. F. Kalicka, J. Brun-Bronowicz. Życie, dziatalność, twórczość, Warszawa 1973, s. 45-47; Zob. M. Nawrot-Borowska, A. Małek, Wychowanie zdrowotne i higiena dzieci i mtodziė̇y w świetle poradników dla rodziców z lat 1850-1970 - zarys problematyki, „Przegląd Pedagogiczny” 2015, nr 2, s. 85-124. 
świat $\mathrm{w}$ warunkach higienicznych pozostawiających wiele do życzenia, matki często po porodzie wracały do swoich obowiązków, zostawiając niemowlęta w kołysce na kilka godzin lub zabierając ze sobą np. na pole. $O$ świadomym wychowaniu fizycznym w tej kwestii trudno mówić w sytuacji, kiedy po odstawieniu od piersi dzieci jadały zwykle to, co dorośli, często, szczególnie na przednówku, nie dojadały, myły się jedynie „od święta”, a tym samym cierpiały na rozliczne choroby ${ }^{56}$. Pospolity był kołtun, funkcjonowały różnorodne zabobony i przesądy związane ze zdrowiem i chorobami. Na skutek niskiego poziomu higieny i utrudnionego dostępu do usług lekarskich (pomocy szukano u babek, znachorów i znachorek, zielarek) odsetek śmiertelności wśród niemowląt i małych dzieci był znaczny ${ }^{57}$. Niemal w każdym domu jakieś dziecko lub kilkoro dzieci umierało w niemowlęctwie lub wieku dziecięcym. Zostawione same sobie, bez opieki dorosłych, ulegały częstym wypadkom, co pociągało za sobą kalectwo, a nawet śmierćs8. W XIX wieku jeszcze w większości rodzin, szczególnie z niższych warstw społecznych, realizacja funkcji edukacyjnej w aspekcie troski o zdrowie i kształtowanie - mówiąc współczesnym językiem - postaw prozdrowotnych nie mogła być więc właściwie realizowana.

\section{Podsumowanie}

Choć istotną trudność w badaniach nad funkcją edukacyjną rodziny w omawianym okresie sprawia złożoność czynników składających się na jej realizację, możną stwierdzić, iż model rodziny jako

56 Bywało, że niektórzy żywili się „różnego rodzaju „zielskiem”. Franciszek Kwas pisał, iż na przednówku, kiedy brakowało zboża, ludzie obrywali kwiaty brzozy, które suszyli, i z domieszką dębowej kory mielili i piekli z tego chleb, od którego często chorowano. F. Kwas, Wspomnienia z mojego życia, Olsztyn 1957, s. 1. „Pamiętam, że w niektórych szczególnie ciężkich dla nas latach [...] matka gotowała nam wykę pozostałą z poprzednich lat, którą jedliśmy z barszczem. Do dzisiaj, po tylu latach czuje niedobry, gorzki smak tej potrawy [...] czasem znalazło się parę centów na kwartę ryżu czy innej kaszy" - wspominał Jan Stryczek, J. Stryczek, Chtopskim piórem, Warszawa 1984, s. 26.

57 Zob. Z. Jabłonowska, Rodzina w XIX i na poczatku XX wieku, w: Przemiany rodziny polskiej, dz. cyt., s. 59.

58 Zob. M. Nawrot-Borowska, Dole i niedole dziecka wiejskiego na terenie ziem polskich w II potowie XIX i poczqtku XX wieku w świetle literatury pamiętnikarskiej, „Problemy Wczesnej Edukacji” 2010, nr 1(11). 
środowiska wychowawczego upowszechniany w XIX stuleciu był na tyle uniwersalny, a nawet atrakcyjny, że mógł być i bywał przyjmowany przez rodziny z różnych warstw społecznych. Pedagogowie i publicyści XIX wieku w większości nie rozróżniali specjalnie funkcji wychowawczych, jakie miały spełniać rodziny należące do poszczególnych warstw społecznych. Sądzono, że każda rodzina, bez względu na jej status społeczny, jest pierwszym i najważniejszym środowiskiem wychowawczym. Rodzina bowiem, niezależnie od jej miejsca w stratyfikacji społecznej, pełniła znaczącą funkcję edukacyjną i kształtowała osobowość dzieci całokształtem organizacji i treści swego życia. Funkcja edukacyjna rodziny realizowała się poprzez wyznawany i wpajany młodemu pokoleniu system wartości, atmosferę domu, występujące w rodzinie wzory zachowań, układ stosunków i relacji w niej panujących, podział ról rodzinnych, czynności wykonywane przez poszczególnych jej członków - domowników. To w rodzinie, od rodziców, dziadków i pozostałych jej członków dzieci uczyły się polskiej mowy, szacunku dla rodzimej tradycji, zasad wiary katolickiej, pobożności, patriotyzmu, poszanowania pracy oraz dla ziemi rozumianej jako Ojczyzna. Szczególną rolę w realizacji funkcji wychowawczych, niezależnie od warstwy społecznej, przypisywano matce, jako patronce domowego ogniska, pierwszej nauczycielce języka ojczystego i zasad wiary, choć w praktyce funkcje edukacyjne pełnili wszyscy domownicy, łącznie z najemnymi siłami pedagogicznymi i służbą. Nauczanie domowe miało uzupełniać lub zastępować kształcenie w szkołach rządowych. Opisany model rodziny i realizacja funkcji edukacyjnej na jej gruncie podlegały zmianom wraz z przemianami cywilizacyjnymi i społeczno-ekonomicznymi, które dokonywały się już od pierwszych dekad XX wieku. Jednak można z całą pewnością stwierdzić, iż wychowanie rodzinne, poprzez realizację funkcji edukacyjnej oraz międzypokoleniowy przekaz wartości wychowawczych, sprawiło, iż społeczeństwo polskie, mimo 123 lat życia pod władaniem zaborców, nie zatraciło swojej tożsamości, przywiązania do tradycji, języka i mogło się odrodzić w wolnej Polsce. 


\section{Bibliografia}

Ariès P., Historia dzieciństwa. Dziecko i rodzina w dawnych czasach, przeł. M. Ochab, Marabut, Gdańsk 1995.

Baranowski B., Życie codzienne wsi między Wartq a Pilica w XIX wieku, PIW, Warszawa 1969.

Bołdyrew A., Matka i dziecko w rodzinie polskiej. Ewolucja modelu życia rodzinnego w latach 1795-1918, Neriton, Warszawa 2008.

Bożek A., Pamiętniki, Śląsk, Katowice 1957.

Brodowska H., Chtopi o sobie i Polsce. Rozwój świadomości spoteczno- narodowej, Ludowa Spółdzielnia Wydawnicza, Warszawa 1984.

Chałasiński J., Kultura i naród, Książka i Wiedza, Warszawa 1968.

Chłosta J., Kazimierz Jaroszyk 1878-1941. O narodowy ksztatt Warmii i Mazur, Pojezierze, Olsztyn 1986.

Denisiuk A., W poszukiwaniu nowej formuty dla dawnych kryteriów wartości. Dylematy wychowania w rodzinie na Pomorzu w drugiej potowie XIX i na poczatku XX stulecia, w: Rodzina jako środowisko wychowawcze w czasach nowożytnych, red. K. Jakubiak, Wydawnictwo Uczelniane WSP, Bydgoszcz 1995.

Drzewiecki Z., Wspomnienia muzyka, Polskie Wydawnictwo Muzyczne, Kraków 1971.

Dunin-Wąsowicz K., Świadomość narodowa chtopów w świetle pamiętników wokresie powstań narodowowyzwoleńczych, „Acta Universitatis Lodziensis. Folia Historica" 1992, nr 45.

Durkheim E., Introduction à la sociologie de la famille, w: tenże, Textes 3. Fonctions sociales et institutions, Les Éditions de Minuit, Paris 1975.

Dziecko w rodzinie i spoteczeństwie. Dzieje nowożytne, red. K. Jakubiak, W. Jamrożek, Wydawnictwo Uczelniane Akademii Bydgoskiej im. Kazimierza Wielkiego, Bydgoszcz 2002.

Encyklopedia wychowawcza, oprac. J.T. Lubomirski, E. Stawski, S. Przystański, J.K. Plebański, Gebethner i Wolff, Warszawa 1881, 1885.

Fałat J., Pamiętniki, Sląski Instytut Narodowy, Katowice 1987.

Fedorowicz J., Konopińska J., Marianna i róże. Życie codzienne w Wielkopolsce w latach 1889-1914 w tradycji rodzinnej, Zysk i S-ka, Poznań 1995.

Grabski S., Pamiętniki, Czytelnik, Warszawa 1989.

Grabski W.J., Blizny dzieciństwa, Instytut Wydawniczy PAX, Warszawa 1971.

Górski K., Pamiętniki. Z rękopisu, z upoważnienia autora opracował, zredagował i posłowiem opatrzył Z. Jędrzyński, Comer, Torun 1995.

Grzybowski R., Zadania wychowawcze rodziny polskiej na Pomorzu Nadwiślańskim w ujęciu „Gazety Grudziadzkiej” z lat 1894-1914, w: Wychowanie w rodzinie od starożytności po wiek $X X$, red. J. Jundziłł, Wydawnictwo Uczelniane WSP, Bydgoszcz 1994.

Hartman S., Wspomnienia lwowskie i inne, Leopoldinum, Wrocław 1994. 
Haufe E., Dziecko i rodzina. Wskazówki ksztatcenia domowego dla matek, wolny przekład z niemieckiego, Nakładem Księgarni T. Paprockiego i S-ki, Warszawa 1892.

Iwanicka Z., Pamiętnik, w: W. Rodowicz, S. Rodowiczowa, Zofia z Rodowiczów Iwanicka, Tryptyk rodzinny, PIW, Warszawa 1999.

Jabłonowska Z., Rodzina w XIX i na poczq̨tku XX wieku, w: Przemiany rodziny polskiej, red. J. Komorowska, Instytut Wydawniczy CRZZ, Warszawa 1975.

Jakubiak K., Edukacja rodziców w polskiej refleksji i praktyce pedagogicznej XIX i XX wieku - do 1939 roku, w: Wychowanie w rodzinie polskiej XIX i XX wieku, red. K. Jakubiak, A. Winiarz, Wydawnictwo Uczelniane WSP, Bydgoszcz 2000.

Jakubiak K., Popularyzacja wychowania rodzinnego dziecka w polskiej literaturze pedagogicznej i czasopiśmiennictwie XIX wieku, w: Rodzina w starożytnym Rzymie, red. J. Jundziłł, Wydawnictwo Uczelniane WSP, Bydgoszcz 1993.

Jakubiak K., Swiat postulowanych wartości życia $i$ wychowania w rodzinach polskich na przetomie XIX i XX wieku, „Prace Naukowe Akademii im. Jana Długosza w Częstochowie. Seria: Pedagogika” 2012, z. 21.

Jakubiak K., Wypracowanie modelu wychowania rodzinnego dziecka w polskiej pedagogice XIX i poczatku XX wieku, w: Rodzina i wychowanie. Ciagtość i zmienność na przestrzeni wieków, red. J. Jundziłł, Wydawnictwo Uczelniane WSP, Bydgoszcz 1995.

Jedynak B., Dom i kobieta w kulturze niewoli, w: Kobieta w kulturze i spoteczeństwie, red. B. Jedynak, Wydawnictwo UMCS, Lublin 1990.

Kabzińska Ł., Rodzina jako podstawowe środowisko wychowawcze w pedagogicznych koncepcjach Królestwa Polskiego z lat 1846-1914, w: Wychowanie w rodzinie polskiej od schytku XVIII do potowy XX wieku, red. K. Jakubiak, A. Winiarz, Wydawnictwo Uczelniane WSP, Bydgoszcz 2000.

Kabzińska Ł., Wychowawcza rola rodziny w opinii pozytywistów warszawskich, w: Wychowanie w rodzinie od starożytności po wiek XX, red. J. Jundziłł, Wydawnictwo Uczelniane WSP, Bydgoszcz 1994.

Kalicka F., J. Brun-Bronowicz. Życie, dziatalność, twórczość, Książka i Wiedza, Warszawa 1973.

Kałwa D., Polska doby rozbiorów i międzywojenna, w: Obyczaje w Polsce. Od średniowiecza do czasów wspótczesnych, red. A. Chwalba, Wydawnictwo Naukowe PWN, Warszawa 2008.

Kon F., Narodziny wieku. Wspomnienia, Książka i Wiedza, Warszawa 1969.

Korzeniowska W., Edukacja i wychowanie różnych warstw spotecznych na ziemiach polskich od drugiej potowy wieku XIX do roku 1918, Oficyna Wydawnicza Impuls, Kraków 2004.

Kufer Kasyldy czyli wspomnienia z lat dziewczęcych. Wybór pamiętników z XVIII i XIX wieku, oprac. D. Stępniewska, B. Walczyna, Nasza Księgarnia, Warszawa 1983.

Kwas F., Wspomnienia z mojego życia, Pojezierze, Olsztyn 1957. 
Leśniakowska M., Dwór polski a idee domu w kulturze europejskiej, w: Dwór polski w XIX wieku. Zjawisko historyczne i kulturowe, red. T. Jaroszewski, Stowarzyszenie Historyków Sztuki, Warszawa 1990.

Ligocki E., Dialog z przesztościa, Czytelnik, Warszawa 1970.

Lutyńska K., Ideologia czasopism rodzinnych Królestwa Polskiego w latach 1860-1880, „Przegląd Nauk Historycznych i Społecznych” 1956, t. 7.

Markowska D., Rodzina wiejska na Podlasiu 1864-1964, Zakład Narodowy im. Ossolińskich, Wrocław 1970.

Michalski G., Wskazania dla edukacji domowej w wybranym czasopiśmiennictwie polskim drugiej potowy XIX $i$ w pierwszych latach XX wieku, w: Nauczanie domowe dzieci polskich od VIII do XX wieku, red. K. Jakubiak, A. Winiarz, Wydawnictwo Akademii Bydgoskiej im. Kazimierza Wielkiego, Bydgoszcz 2005.

Mędrzecki W., Intymność i sfera prywatna w życiu codziennym i obyczajach rodziny wiejskiej w XIX i pierwszej potowie XIX wieku, w: Rodzina - prywatnośc intymność. Dzieje rodziny polskiej w kontekście europejskim, red. D. Kałwa, A. Walaszek, A. Żarnowska, Wydawnictwo DiG, Warszawa 2005.

Nauczanie domowe dzieci polskich od VIII do XX wieku, red. K. Jakubiak, A. Winiarz, Wydawnictwo Akademii Bydgoskiej im. Kazimierza Wielkiego, Bydgoszcz 2004.

Nawrot-Borowska M., Nauczanie domowe na ziemiach polskich w II potowie $X I X$ i na poczatku XX wieku - zapatrywania teoretyczne i praktyka, $\mathrm{W}_{\mathrm{y}}$ dawnictwo UKW, Bydgoszcz 2011.

Nawrot-Borowska M., Sprawy tajemne i nieczyste. Rola rodziny w wychowaniu seksualnym dzieci w drugiej potowie XIX $i$ na początku XX wieku w świetle poradników. Zarys problematyki, w: Wychowanie w rodzinie. Od starożytnej myśli filozoficznej do wspótczesnych rozwiąań legislacyjnych, t. 7, red. B. Jędrychowska, E. Jurczyk-Romanowska, Zakład Historii Edukacji Instytutu Pedagogiki Uniwersytetu Wrocławskiego - Wydział Nauk Humanistycznych i Społecznych Karkonoskiej Państwowej Szkoły Wyższej, Wrocław - Jelenia Góra 2013.

Nawrot-Borowska M., Edukacja patriotyczna w rodzinach polskich w II potowie XIX i na poczq̨tku XX wieku w świetle literatury pamiętnikarskiej, w: Niepodlegtość $i$ wychowanie: z doświadczeń II Rzeczypospolitej, red. W. Jamrożek, E. Kula, M. Pękowska, Wydawnictwo Wszechnicy Świętokrzyskiej, Kielce 2012.

Nawrot-Borowska M., Małek A., Wychowanie zdrowotne i higiena dzieci i mtodzieży w świetle poradników dla rodziców z lat 1850-1970 - zarys problematyki, „Przegląd Pedagogiczny”2015, nr 2.

Partnerka, matka, opiekunka. Status kobiety w dziejach nowożytnych od VI do $X X$ wieku, red. K. Jakubiak, Wydawnictwo Uczelniane WSP, Bydgoszcz 2000.

Pawlikowski M., Pamiętniki. Medyka - Kraków - Zakopane, Wydawnictwo Literackie, Kraków 1998. 
Pigoń S., Z Komborni w świat. Wspomnienia mtodości, Ludowa Spółdzielnia Wydawnicza, Warszawa 1983.

Raczyński E., Rogalin i jego mieszkańcy, Rada Miejska Poznania, Poznań 1991.

Regulska A., Przeobrażenia w modelu i funkcjach rodziny na przestrzeni XIX-XX wieku, „Studia nad Rodziną” 2011, nr 1-2.

Rodzina - prywatność - intymnośc. Dzieje rodziny polskiej w kontekście europejskim, red. D. Kałwa, A. Walaszek, A. Żarnowska, Wydawnictwo DiG, Warszawa 2005.

Rodzina jako środowisko wychowawcze w czasach nowożytnych, red. K. Jakubiak, Wydawnictwo Uczelniane WSP, Bydgoszcz 1995.

Rodzina. Historia i wspótczesność. Studium monograficzne, red. W. Korzeniowska, U. Szuścik, Oficyna Wydawnicza Impuls, Kraków 2010.

Rodzina pomorska, red. J. Borzyszkowski, Nadbałtyckie Centrum Kultury, Instytut Kaszubski, Gdańsk 1999.

Rzepniewska D., Rodzina ziemiańska w Królestwie Polskim, w: Spoteczeństwo polskie XVIII i XIX wieku. Studia o rodzinie, t. 9, red. J. Leskiewiczowa, PWN, Warszawa 1991.

Siennicka M., Rodzina burżuazji warszawskiej i jej obyczaj. Druga potowa XIX i poczatek XX wieku, Wydawnictwo DiG, Warszawa 1998.

Sobczak J., Przejawy zainteresowania wychowaniem rodzinnym w pracach niektórych polskich pisarzy i pedagogów u schytku XVIII $i$ w pierwszej potowie XIX wieku, „Zeszyty Naukowe Wyższej Szkoły Pedagogicznej w Bydgoszczy. Studia Pedagogiczne” 1992, z. 18.

Sobczak J., Warunki i przejawy rozwoju teorii wychowania rodzinnego i edukacji rodziców od czasów odrodzenia, w: Rodzina. Przesztość-teraźniejszość-przysztość, red. A. Tchorzewski, Wydawnictwo Uczelnianie WSP, Bydgoszcz 1988.

Stryczek J., Chtopskim piórem, Ludowa Spółdzielnia Wydawnicza, Warszawa 1984.

Szarkowska A., Wychowanie religijne w rodzinie polskiej w okresie zaborów, „Kultura i Edukacja” 2003, nr 3/4.

Szczepański J., Korzeniami wrostem w ziemię, Śląsk, Katowice 1984.

Tchorzewski A.M., Funkcje edukacyjne rodziny. Studium diagnostyczno-anagnostyczne, Wydawnictwo Uczelniane WSP, Bydgoszcz 1990.

Trzeciakowscy M. i L., $W$ dziewiętnastowiecznym Poznaniu. Życie codzienne miasta 1815-1914, Wydawnictwo Poznańskie, Poznań 1987.

Wierzbicki A., Żywy Lewiatan, Krajowa Agencja Wydawnicza, Warszawa 2001.

Witkiewiczówna M., Wspomnienia o Stanistawie Witkiewiczu, Gebethner i Wolff, Warszawa 1936.

Witos W., Moje wspomnienia, Ludowa Spółdzielnia Wydawnicza, Warszawa 1978.

Wójcik M., Znaczenie wychowawcze pielgrzymek rodzin górnoślaskich do miejsc kultu narodowego w latach 1896-1914, w: Rodzina jako srodowisko wychowarwcze w czasach nowożytnych, red. K. Jakubiak, Wydawnictwo Uczelniane WSP, Bydgoszcz 1995. 
Wychowanie w rodzinie od starożytności po wiek XX, red. J. Jundziłł, Wydawnictwo Uczelniane WSP, Bydgoszcz 1994.

Wychowanie w rodzinie polskiej od schytku XVIII do potowy XX wieku, red. K. Jakubiak, A. Winiarz, Wydawnictwo Uczelniane WSP, Bydgoszcz 2000.

Wychowanie w rodzinie. Przekaz tradycji i kultury na przestrzeni wieków, t. 1, red. S. Walasek, L. Albański, Karkonoska Szkoła Wyższa w Jeleniej Górze, Jelenia Góra 2011.

Wychowanie w rodzinie. Rodzina na przestrzeni wieków, t. 2, red. S. Walasek, L. Albański, Karkonoska Szkoła Wyższa w Jeleniej Górze, Jelenia Góra 2011. Wychowanie w rodzinie. Od starożytnej mysli filozoficznej do wspótczesnych rozwiqzzań legislacyjnych, t. 7, red. B. Jędrychowska, E. Jurczyk-Romanowska, Zakład Historii Edukacji Instytutu Pedagogiki Uniwersytetu Wrocławskiego - Wydział Nauk Humanistycznych i Społecznych Karkonoskiej Państwowej Szkoły Wyższej, Wrocław - Jelenia Góra 2013.

Wychowanie w rodzinie. Rodzina w Europie na przetomie XIX i XX wieku, t. 12, red. S. Walasek, A. Haratyk, Zakład Historii Edukacji Instytutu Pedagogiki Uniwersytetu Wrocławskiego - Wydział Nauk Humanistycznych i Społecznych Karkonoskiej Państwowej Szkoły Wyższej, Wrocław - Jelenia Góra 2016.

Zabielski F., Z życia i z pamięci, Ludowa Spółdzielnia Wydawnicza, Warszawa 1980.

Źródta do dziejórw wychowania w rodzinie polskiej w XIX i poczatkach XX wieku, wybór i oprac. A. Denisiuk, K. Jakubiak, Wydawnictwo Akademii Bydgoskiej im. Kazimierza Wielkiego, Bydgoszcz 2001.

Źródta do nauczania domowego dzieci polskich w XIX i na początku XX wieku z bibliografiq adnotowana pamiętników i wyborem literatury pedagogicznej, red. K. Jakubiak, G. Karłowska, M. Nawrot, A. Winiarz, Wydawnictwo Akademii Bydgoskiej im. Kazimierza Wielkiego, Bydgoszcz 2005.

Żanowska A., Rodzina robotnicza w Warszawie na przetomie XIX i XX wieku, „Kronika Warszawy” 1984, nr 2.

Żyrowski M., Dziewiętnastowieczna rodzina polska, „Roczniki Socjologii Rodziny" 2000, z. 12.

\section{ADRES DO KORESPONDENCJ}

Prof. dr hab. Krzysztof Jakubiak

Uniwersytet Gdański

Wydział Nauk Społecznych, Instytut Pedagogiki

ola_jakubiak@interia.pl

Dr Monika Nawrot-Borowska

Uniwersytet Kazimierza Wielkiego w Bydgoszczy

Wydział Pedagogiki i Psychologii, Instytut Pedagogiki

mnawrot10@wp.pl 